CLINICAL STUDY

\title{
Pro- and mature IGF-II during diet-induced weight loss in obese subjects
}

\author{
Ulrick Espelund, Jens Meldgaard Bruun, Bjørn Richelsen, Allan Flyvbjerg and Jan Frystyk \\ Medical Research Laboratories, Clinical Institute and Medical Department C and M, Aarhus University Hospital, Aarhus C, Denmark
}

(Correspondence should be addressed to U Espelund; Email: uen@studmed.au.dk

\begin{abstract}
Background: In normal subjects up to $10 \%$ of circulating insulin-like growth factor II (IGF-II) consists of pro-IGF-II. However, its regulation and biological impact remains unknown. In obese subjects, serum free and total IGF-II are increased, and we therefore investigated the impact of obesity and diet on serum pro-IGF-II.

Design: Non-diabetic, obese subjects $(n=34)$ with a body mass index (BMI) of $38.9 \pm 0.5 \mathrm{~kg} / \mathrm{m}^{2}$ were subjected to 8 weeks with very low calorie diet $(800 \mathrm{kcal} /$ day) followed by 12 weeks with a weightstabilizing diet. Fasting serum was collected before the study, and after 8 and 20 weeks. Pro-IGF-II was determined after acid-gel chromatography using a novel, highly specific in-house assay, free and total IGFs were measured after ultrafiltration and acid-ethanol extraction, respectively, and IGF-binding proteins (IGFBPs) were measured with specific immunoassays.

Results: Diet reduced BMI and fasting levels of insulin and glucose $(P<0.001)$. Serum pro-IGF-II was markedly reduced in obese subjects as compared with matched normal-weight controls (means and 95\% confidence intervals: $93 \mu \mathrm{g} / \mathrm{l}(82-104 \mu \mathrm{g} / \mathrm{l})$ versus $171 \mu \mathrm{g} / \mathrm{l}(152-192 \mu \mathrm{g} / \mathrm{l})$, respectively; $P<0.001$ ), and levels remained unchanged after the weight loss. In contrast, during the study period total and free IGF-II decreased $(P<0.05)$, whereas total IGF-I, IGFBP-1 and IGFBP-2 increased $(P<0.001)$. Serum free IGF-I remained unaltered. Cross-sectional and longitudinal correlation analyses showed that pro-IGF-II was closer and more consistently associated with IGF-I than IGF-II. Conclusion: This study demonstrates that pro-IGF-II is reduced in obesity, in contrast to mature IGF-II. This indicates a hitherto unrecognized link between nutrition and pro-IGF-II. In addition, our data indicate that pro-IGF-II is regulated independently of mature IGF-II.
\end{abstract}

European Journal of Endocrinology 153 861-869

\section{Introduction}

The insulin-like growth factor (IGF) system plays a central role in the processes that control cell proliferation, differentiation and apoptosis (1, 2). IGF-I and IGF-II are the primary growth-promoting members of the IGF system, and in adult life they mediate their anabolic effects through interaction with the IGF-I receptor (IGF-IR), which is a transmembrane tyrosine kinase receptor distributed throughout the body (3). There are, however, other receptors which may be activated by the IGFs. The IGF-II/mannose 6-phosphate receptor (IGF-II/Man-6-PR) is a single-chain receptor with two different binding sites, one for IGFs and one for mannose 6-phosphate-containing proteins (4). The IGFII/Man-6-PR recognizes IGF-II as well as IGF-I, the latter with lower affinity, while insulin does not bind (5). After ligand binding to the IGF-II/Man-6-PR, the entire complex is internalized and degraded, for which reason it has been suggested to serve as a scavenger receptor, reducing peri-cellular levels of IGF-II $(1,6)$. Some controversy exists as to whether binding of IGF-II to the IGF-II/Man-6-PR elicits biological signals (4). Moreover, IGF-II binds with low affinity to insulin receptor (IR) subtype B (2\% compared with insulin) and with high affinity to IR subtype A (15\% compared with insulin) (7). The latter receptor is able to exert metabolic as well as mitogenic effects depending on whether it is activated by insulin or IGF-II (8).

The Igf2 gene encodes a 180-amino acid protein known as pre-pro-IGF-II, which consists of a 24amino acid signal peptide at the N-terminus, the 67amino acid mature IGF-II peptide and an 89-amino acid extension (the E-peptide) at the C-terminus (9). After cleavage of the signal peptide, the 156-amino acid pro-IGF-II becomes glycosylated and cleaved in the Golgi apparatus, resulting in a 104-amino acid peptide (10). Two additional cleavages takes place, probably at the time of secretion, finally yielding mature $7.5 \mathrm{kDa}$ IGF-II (11). A fraction of the 
synthesized pro-IGF-II is not cleaved and exits the cell as larger peptides of $10-18 \mathrm{kDa}$, generally referred to as big IGF-II.

The pro-forms of IGF-II have been detected in serum as well as in cerebrospinal and amniotic fluids (12). In serum from healthy subjects the concentration of pro-IGF-II constitutes roughly $10-15 \%$ of circulating IGF-II $(13,14)$. The regulation and biological role of pro-IGF-II is unknown, but its insulin-like bioactivity has been shown to be 3 -fold increased in the rat fatcell bioassay as compared with mature IGF-II (14). Increased serum pro-IGF-II has been a key finding in non-islet cell tumour hypoglycaemia (NICTH), where it is thought to play a pathogenetic role in the development of hypoglycaemia $(15,16)$.

The aim of the present study was 2-fold: first, to learn more about the regulation of pro-IGF-II, we wanted to develop a specific immunoassay for measurement of levels in serum; second, we aimed to investigate the possible nutritional regulation of pro-IGF-II. For this purpose we studied lean and obese subjects. Obesity was chosen because this is a condition where serum levels of free as well as total IGF-II appear to be upregulated (17).

\section{Materials and methods}

\section{Pro-IGF-II assay buffers}

The pro-IGF-II assay was performed using the following buffers: coating buffer ( $40 \mathrm{mmol} / \mathrm{l}$ phosphate, $\mathrm{pH} 8.0$, $9 \mathrm{~g} / \mathrm{l} \mathrm{NaCl}, 2 \mathrm{~g} / \mathrm{l}$ human serum albumin (HSA), $2 \mathrm{ml} / \mathrm{l}$ Tween 20 and $1.6 \mathrm{~g} / \mathrm{l}$ diethylenetriaminepenta-acetate (DTPA)), wash solution $(50 \mathrm{mmol} / \mathrm{l}$ Tris/HCl, $\mathrm{pH} 8.0$, $9 \mathrm{~g} / \mathrm{lNaCl}, 5 \mathrm{ml} / \mathrm{l}$ Tween 20 and $\left.0.5 \mathrm{~g} / \mathrm{lNaN}_{3}\right)$ and assay buffer $(400 \mathrm{mmol} / \mathrm{l}$ Tris buffer, $9 \mathrm{~g} / \mathrm{lNaCl}, 2 \mathrm{~g} / \mathrm{l}$ HSA, $2 \mathrm{ml} / \mathrm{l}$ Tween 20 and $1.6 \mathrm{~g} / \mathrm{l} \mathrm{DTPA})$. The $\mathrm{pH}$ of the assay buffer was 8.50 before and 7.80 after mixing with an equal volume of $200 \mathrm{mmol} / \mathrm{l}$ acetic acid. The buffer used for acid-gel chromatography was $200 \mathrm{mmol} / \mathrm{l}$ acetic acid with $2 \mathrm{~g} / \mathrm{l} \mathrm{BSA}$ and $2 \mathrm{ml} / \mathrm{l}$ Tween 20. All buffer reagents were from Sigma-Aldrich (Brøndby, Denmark) with the exception of HSA, which was obtained from ICN Biomedical (Aurora, OH, USA).

\section{Pro-IGF-II antigen and pro-IGF-II antibodies}

Pro-IGF-II was detected by a novel, in-house, timeresolved immunofluorometric assay (TR-IFMA) based on commercial reagents. A polyclonal rabbit antibody (GroPep, Adelaide, Australia) directed against amino acids 78-88 of the E-peptide of recombinant human pro-IGF-II was used for coating. Since mature IGF-II consists of 67 amino acids, this coating antibody was highly specific for pro-IGF-II. Recombinant human pro-IGF-II containing amino acids 1-104 (GroPep) served as assay standard. A recombinant monoclonal rat IGF-II antibody (clone S1F2; Upstate Biotechnology, Charlottesville, VA, USA) was used for detection after being labelled with europium using an $\mathrm{Eu}^{3+}$ labelling kit (PerkinElmer Life Sciences, Turku, Finland) according to the manufacturer's instructions.

\section{Assay principle}

Ninety-six-well microtitre plates pre-coated with polyclonal goat anti-rabbit IgG (PerkinElmer Life Sciences) were washed once with an automated plate washer and added $200 \mu \mathrm{l}$ per well of pro-IGF-II antibody diluted 1:900 in coating buffer. After overnight incubation at $5{ }^{\circ} \mathrm{C}$ all wells were washed once, and then $100 \mu \mathrm{l}$ assay buffer and $100 \mu \mathrm{l}$ of either standard (a serial dilution of recombinant human pro-IGF-II ranging from 0.125 to $4.0 \mu \mathrm{g} / \mathrm{l}$ ) or unknown sample was added. After mixing for $5 \mathrm{~min}$, the microtitre plates were incubated overnight at $5{ }^{\circ} \mathrm{C}$. The following day all wells were washed once and incubated at ambient temperature for $3.5 \mathrm{~h}$ with $200 \mu \mathrm{Eu}^{3+}$-labelled IGF-II antibody dissolved in coating buffer. Afterwards, all wells were washed six times, and $200 \mu$ l Enhancement Solution (PerkinElmer Life Sciences) added before timeresolved fluorometry was performed according to the manufacturer (PerkinElmer Life Sciences).

\section{Assay validation}

IGF-I and -II cross-reactivity was estimated by addition of serial dilutions up to $10000 \mu \mathrm{g} / \mathrm{l}$ recombinant human IGF-I and -II (both from Austral Biologicals, San Ramon, CA, USA). The within-assay coefficients of variation (CVs) for standards and samples were calculated as the respective means. The between-assay $\mathrm{CV}$ was estimated from repetitive measurement of a pro-IGF-II standard $(1 \mu \mathrm{g} / \mathrm{l})$.

\section{Serum extraction of pro-IGF-II}

Pilot studies proved the necessity of extracting pro-IGFII from the IGF-binding proteins (IGFBPs) prior to assay. Initially, we tried an acid-ethanol extraction method similar to the one used in our laboratory for mature IGF-I and -II (18), but this method yielded an unsatisfactory recovery $(<80 \%)$ due to co-precipitation of pro-IGF-II. It was therefore chosen to separate pro-IGF-II from the IGFBPs by acid size-exclusion gel chromatography, using $20 \mathrm{ml}$ open columns $(1.5 \times 12 \mathrm{~cm}$; BioRad Laboratories, Hercules, CA, USA) packed with Sephadex G-50 Superfine (Amersham Biosciences, Uppsala, Sweden). These columns allowed acidified serum to be eluted within $1 \mathrm{~h}$, enabling the processing of several serum samples within one working day. The elution protocol was as follows: $75 \mu \mathrm{l}$ serum were added $325 \mu \mathrm{l} 1 \mathrm{~mol} / \mathrm{l}$ acetic acid and incubated for approximately $20 \mathrm{~min}$ at ambient temperature. Then $300 \mu \mathrm{l}$ were loaded onto the column and eluted with chromatography buffer. Fractions of $1 \mathrm{ml}$ were collected manually and assayed 
for IGFBP-2, pro-IGF-II, and IGF-I and -II. The separation of pro-IGF-II from the IGFBPs was investigated by measurement of IGFBP-2 using a highly specific and sensitive in-house TR-IFMA as previously described (19). Mature IGF-I and -II were measured using previously described in-house TR-IFMAs (18). In all assays the acidified fractions were neutralized with $400 \mathrm{mmol} / \mathrm{l}$ Tris buffer, and assay standards contained the same amount of acetic acid as the unknown samples. Column recovery was assessed by acid-gel filtration of exogenous pro-IGF-II $(100 \mu \mathrm{g} / \mathrm{l}$ dissolved in $0.2 \mathrm{~mol} / \mathrm{l}$ acetic acid with $0.2 \%$ HSA) according to the protocol described above.

\section{Other assays}

Glucose was determined using the glucose oxidation method (Beckman Instruments, Fullerton, CA, USA). Serum insulin was determined with a commercially available kit (DakoCytomation A/S, Glostrup, Denmark). Total IGF-I and -II, free IGF-I and -II and IGFBP-1 and IGFBP-1-bound IGF-I were determined by validated in-house assays (18-21).

\section{Clinical study}

To study the possible nutritional regulation of pro-IGF-II, we compared fasting serum samples from age- and gender-matched groups of lean (11 males and 13 females, age $40.5 \pm 2.2$ years, body mass index (BMI) $\left.23.6 \pm 0.5 \mathrm{~kg} / \mathrm{m}^{2}\right)$ and non-diabetic obese subjects (13 males and 21 females, age $44.3 \pm 1.6$ years, BMI $38.9 \pm 0.5 \mathrm{~kg} / \mathrm{m}^{2}$ ). We only had access to a limited serum sample volume from the healthy controls, and therefore only pro-IGF-II was measured in this group. In contrast, we were able to perform a more detailed study of the changes in the circulating IGF system in the obese subjects before and after a diet-induced weight loss. During the diet program, the obese subjects received a very low calorie diet (VLCD; approximately $800 \mathrm{kcal} /$ day) for 8 weeks followed by 12 weeks on a weight-stabilizing diet (a $600 \mathrm{kcal}$ reduction in the total energy need per day; Fig. 1). The latter was estimated by calculations based on height, sex, level of physical activity and others. Fasting blood samples were obtained from the vein before commencement of the diet

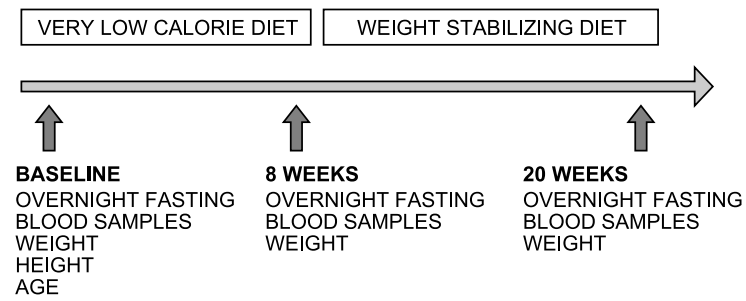

Figure 1 Study design: obese subjects participated in a 20-week weight-loss program with 8 weeks on a VLCD followed by 12 weeks on a weight-stabilizing diet. (baseline), after the 8 weeks of VLCD and again at the end of the study after a total of 20 weeks of diet. Serum was separated and frozen at $-20^{\circ} \mathrm{C}$ until analysis. The diet study was performed at Medical Department C, Aarhus University Hospital, Denmark. Metabolic data from the diet study have been published previously (22). All patients gave their informed written consents, and the study was approved by the local ethics committee.

\section{Statistics}

All data were natural-log-transformed prior to statistical analysis to improve the normal distribution, which was subsequently confirmed by normality plots for each variable. Changes over time were assessed with one-way analysis of variance (ANOVA) for repeated measurements. A significant ANOVA was followed by the Student-Newman-Keuls method for pairwise multiple comparisons. For comparison of two independent groups, Student's unpaired $t$-test was used. Correlation coefficients were made to relate changes in the IGF system to changes in BMI/insulin, and to look for possible modifiers of pro-IGF-II levels. A $P$ value of less than 0.05 was considered statistically significant. Data are means \pm S.E.M.

\section{Results}

\section{Pro-IGF-II assay}

A representative standard curve is shown in Fig. 2. The non-specific background signal averaged $\sim 600$ c.p.s., and the lowest pro-IGF-II standard was $\sim 1300$ c.p.s. The assay detection limit (non-specific background signal +3 s.D.) was estimated at $0.08 \mu \mathrm{g} / \mathrm{l}$. The withinassay CVs for standards and samples averaged 2.5 and $3.7 \%$, respectively (seven set-ups). The between-assay CV was $10 \%$. The pro-IGF-II TR-IFMA was highly

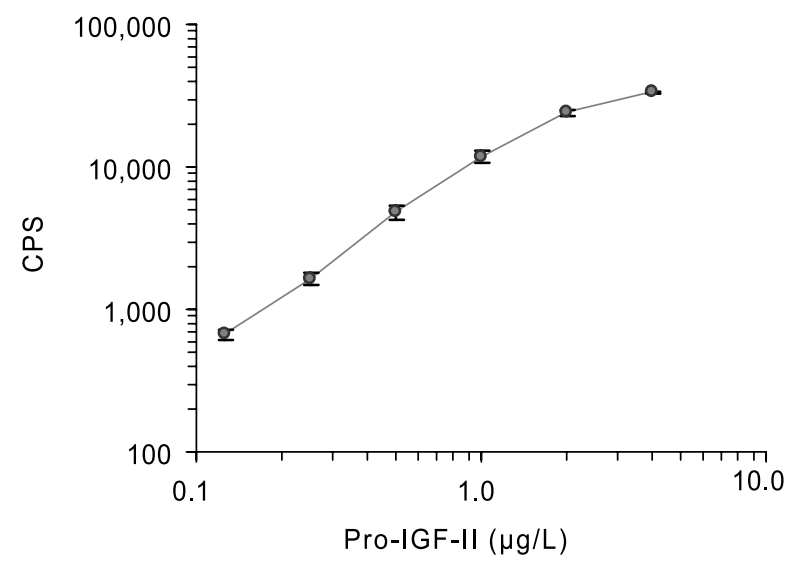

Figure 2 A representative standard curve of the pro-IGF-II TR-IFMA. Data are means \pm S.E.M.CPS, counts per second. 


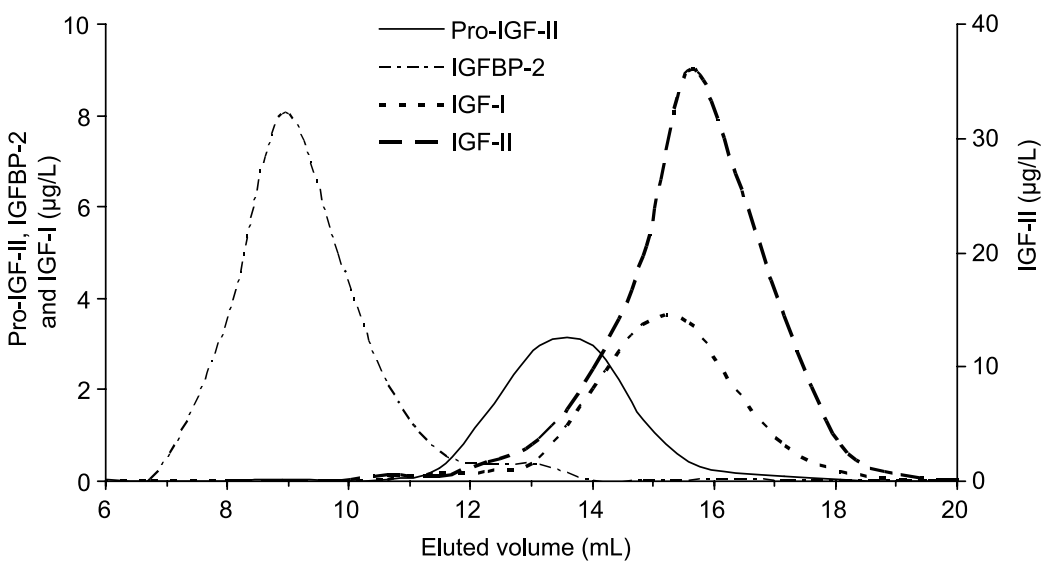

Figure 3 The average elution profile of four normal serum samples. Serum $(75 \mu \mathrm{l})$ was acidified with $350 \mu \mathrm{l}$ acetic acid ( $1 \mathrm{~mol} / \mathrm{l})$, incubated for $20 \mathrm{~min}$ at ambient temperature, whereafter $300 \mu \mathrm{l}$ was loaded onto a $20 \mathrm{ml}$ open column containing Sephadex G-50 superfine gel. The column was eluted with $200 \mathrm{mmol} / \mathrm{l}$ acetic acid containing BSA and Tween 20. Fractions of $1 \mathrm{ml}$ were collected and assayed as described in the Materials and methods section. specific: IGF-I showed no detectable cross-reactivity and IGF-II yielded a signal of less than $0.2 \mu \mathrm{g} / \mathrm{l}$ when added at a concentration of $10000 \mu \mathrm{g} / \mathrm{l}$. Conversely, proIGF-II (up to $10000 \mu \mathrm{g} / \mathrm{l}$ ) did not cross-react in the IGF-I assay, but cross-reacted with $20 \%$ in the IGF-II assay.

An acid-gel chromatography profile based on the mean of four normal serum samples is shown in Fig. 3. The $20 \mathrm{ml}$ columns provided an almost complete separation between pro-IGF-II and the IGFBPs as estimated by measurement of IGFBP-2, and based on these profiles we decided to pool the fractions eluting between 12 and $19 \mathrm{ml}$ for later analysis of pro-IGF-II (Fig. 3). As compared with the overall amount, this $7 \mathrm{ml}$ pool contained more than $97 \%$ of the total eluted amount of IGF-I, IGF-II and pro-IGF-II. After acid-gel chromatography, the recovery of exogenous pro-IGF-II was estimated to be $105 \%$. We assessed NICTH serum for pro-IGF-II levels after acid-gel chromatography and found that levels were four or five times higher than in control serum obtained from healthy blood donors (data not shown). The column-to-column CV was 4\%. The overall CV of unknown samples including column-to-column and assay-to-assay variation was estimated to be $14 \%$ (one serum sample gel-filtrated 18 times on different days and different columns).

\section{Clinical study}

Twenty weeks of diet reduced the body weight, BMI and fasting levels of insulin and glucose (Table 1). Serum pro-IGF-II was markedly reduced in obese subjects compared with matched normal-weight controls (mean and 95\% confidence interval: $93 \mu \mathrm{g} / \mathrm{l}(82-104 \mu \mathrm{g} / \mathrm{l})$ versus $171 \mu \mathrm{g} / \mathrm{l}(152-192 \mu \mathrm{g} / \mathrm{l})$, respectively; $P<0.001)$, and levels remained unchanged after weight loss (Table 1, Fig. 4). In contrast, both total and free IGFII decreased after diet (Table 1, Fig. 5). Total IGF-I shoved a gradual increase over the period, whereas free IGF-I remained constant (Table 1, Fig. 5). IGFBP1 and -2 both increased during the diet (Table 1 , Fig. 6). The binary complex consisting of IGF-I bound to IGFBP-1 increased (Table 1, Fig. 6).

Changes in BMI and insulin were compared with changes in IGF parameters by correlation analysis (Table 2). Interestingly, longitudinal changes in proIGF-II levels from baseline to weeks 8 and 20, respectively, correlated with changes in total IGF-I levels (Table 2). Furthermore, a cross-sectional analysis

Table 1 Metabolic and IGF-related parameters during the diet study. Data are given as means \pm S.E.M.

\begin{tabular}{|c|c|c|c|c|}
\hline & Baseline & Week 8 & Week 12 & ANOVA $P$ - value \\
\hline BMI $\left(\mathrm{kg} / \mathrm{m}^{2}\right)$ & $38.9 \pm 0.5$ & $34.5 \pm 0.6$ & $33.8 \pm 0.7$ & $<0.001$ \\
\hline Weight (kg) & $114.3 \pm 2.6$ & $101.6 \pm 2.4$ & $99.3 \pm 2.6$ & $<0.001$ \\
\hline Insulin (pmol/l) & $101 \pm 7$ & $74 \pm 5$ & $81 \pm 6$ & $<0.001$ \\
\hline Glucose (mmol/l) & $6.3 \pm 0.1$ & $5.2 \pm 0.2$ & $5.3 \pm 0.2$ & $<0.001$ \\
\hline Pro-IGF-II $(\mu \mathrm{g} / \mathrm{I})$ & $93 \pm 5$ & $96 \pm 7$ & $100 \pm 8$ & NS \\
\hline Total IGF-II ( $\mu \mathrm{g} / \mathrm{I})$ & $1124 \pm 48$ & $1018 \pm 43$ & $1043 \pm 44$ & 0.049 \\
\hline Total IGF-I ( $\mu \mathrm{g} / \mathrm{l})$ & $111 \pm 5.5$ & $127 \pm 8.6$ & $141 \pm 9.2$ & $<0.001$ \\
\hline Free IGF-I ( $\mu \mathrm{g} / \mathrm{l})$ & $1.32 \pm 0.09$ & $1.48 \pm 0.10$ & $1.33 \pm 0.09$ & NS \\
\hline IGFBP-1 $(\mu \mathrm{g} / \mathrm{l})$ & $13.5 \pm 1.8$ & $21.5 \pm 3.8$ & $23.8 \pm 4.0$ & $<0.001$ \\
\hline IGFBP-2 ( $\mu \mathrm{g} / \mathrm{l})$ & $347 \pm 22$ & $505 \pm 38$ & $433 \pm 29$ & $<0.001$ \\
\hline IGFBP1 bound IGF-I ( $\mu \mathrm{g} / \mathrm{I})$ & $2.4 \pm 0.6$ & $4.3 \pm 0.5$ & $5.8 \pm 1.4$ & $<0.001$ \\
\hline
\end{tabular}

NS, not significant. 


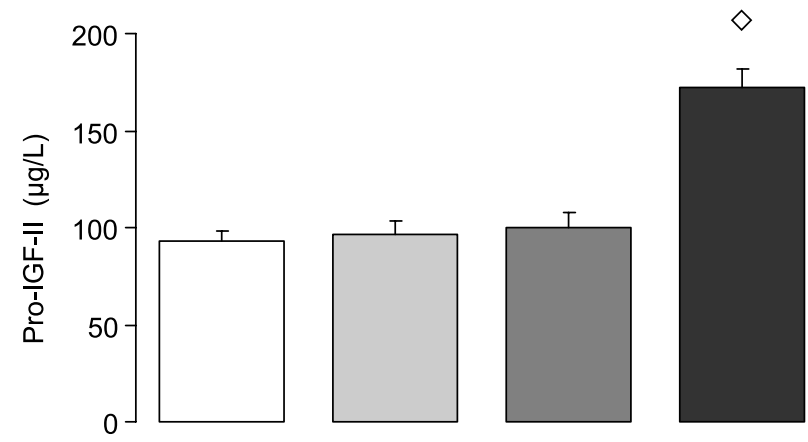

Figure 4 Pro-IGF-II levels in obese and normal-weight subjects. Columns represent (left to right) levels in obese subjects at baseline, 8 weeks and 20 weeks, and levels in normal-weight controls (means \pm S.E.M.). $\diamond P<0.05$ compared with baseline, 8 weeks and 20 weeks.

unmasked a correlation between pro-IGF-II and both total and free IGF-I levels at all three sample times (baseline, 8 weeks and 20 weeks; Table 3).

\section{Discussion}

The present study describes the development of a highly specific and sensitive sandwich assay for detection of human pro-IGF-II, and its application in serum samples from lean and obese subjects. The assay is based on an immobilized polyclonal antibody directed against the E-peptide of pro-IGF-II, and a monoclonal detection antibody directed against mature IGF-II. This principle ensures that intact pro-IGF-II is fully detectable, whereas any free E-peptide is ignored. Using this assay we have been able to demonstrate that proIGF-II is reduced in obesity, indicating a hitherto unrecognized link between nutrition and pro-IGF-II.

A number of methods have been described for measurement of pro-IGF-II. The first assessment of pro-IGF-II levels was made by Daughaday et al. (23) using acidic size-exclusion gel chromatography and subsequent IGF-II measurement of the collected fractions by RIA based on a polyclonal antibody against IGF-II. This yielded an elution profile of the IGF-II immunoreactivity, and by calculating the peak sizes the ratio of pro- to mature IGF-II was determined (23). Using a similar technique, Zapf et al. (14) found three peaks of IGF-II immunoreactivity: one for pro-IGF-II, one for IGF-II dimers and one for mature, monomeric IGF-II. The fractions corresponding to the first peak was assessed in the IGF-II assay and the result interpreted as pro-IGF-II levels (14). These methods gave important information on the molecular size of pro-IGF-II and eliminated interference from the
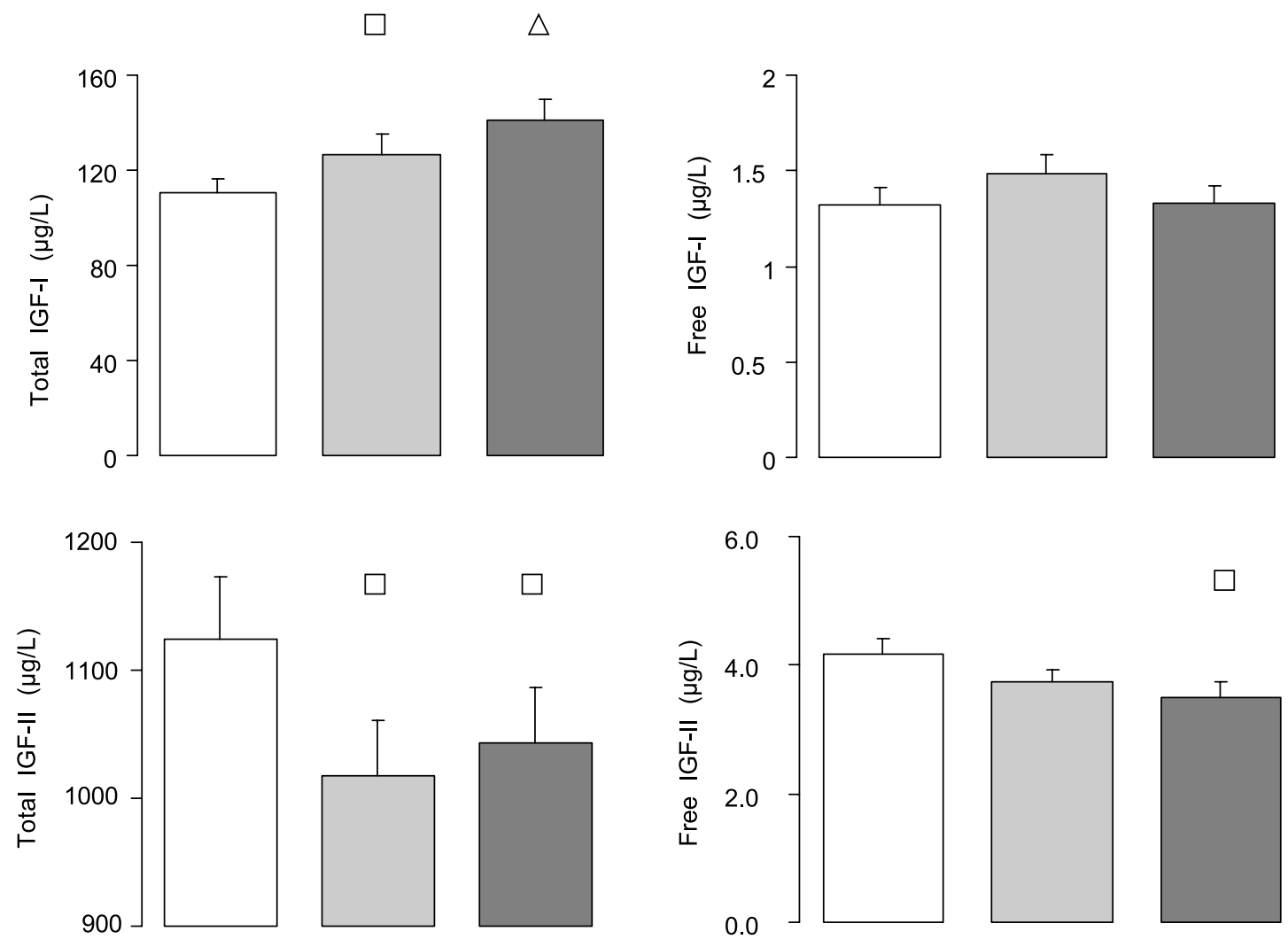

Figure 5 Free and total IGF levels in obese subjects. Columns represent (left to right) levels in obese subjects at baseline, 8 weeks and 20 weeks (means \pm S.E.M.). $\square P<0.05$ compared with baseline; $\Delta P<0.05$ compared with baseline and 8 weeks. 

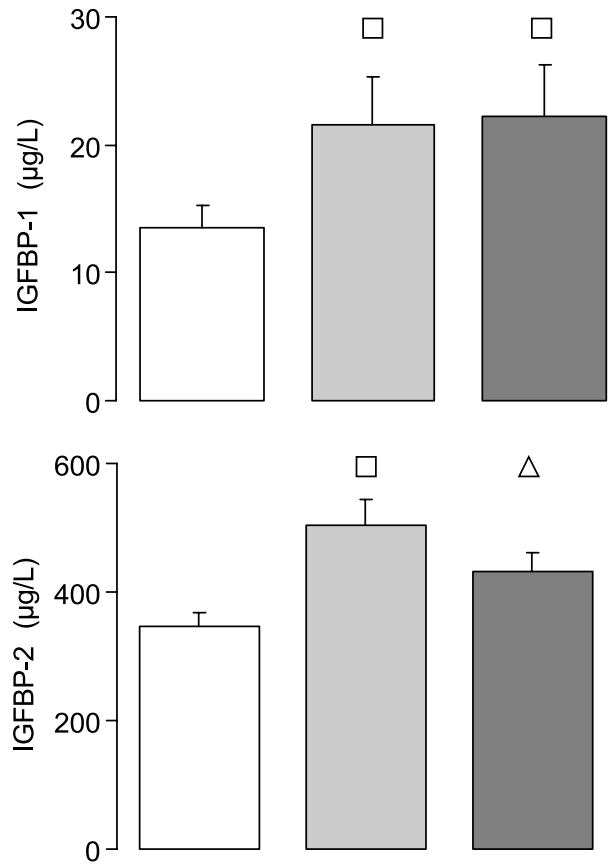

$\triangle$
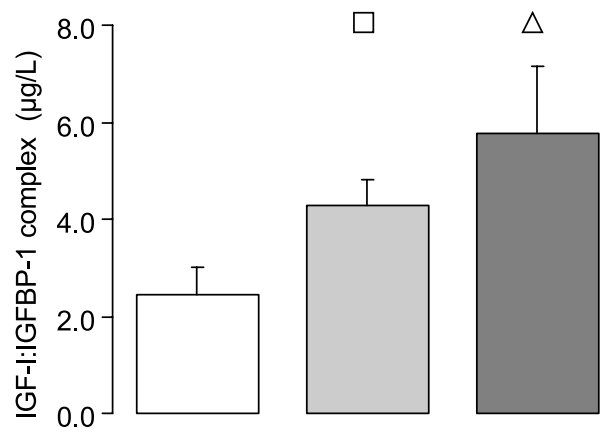

Figure 6 IGFBP-1, IGFBP-2 and IGFBP-1-bound IGF-I levels in obese subjects. Columns represent (left to right) levels in obese subjects at baseline, 8 weeks and 20 weeks (means \pm S.E.M.). $\square P<0.05$ compared with baseline; $\Delta P<0.05$ compared with baseline and 8 weeks.

IGFBPs. Major drawbacks are the multiple IGF-II determinations required per patient sample and the time-consuming methodology. In addition, it has been speculated that the use of an antibody directed against mature IGF-II due to a lower affinity for pro-IGF-II may result in an underestimation of pro-IGF-II levels (13).

The development of specific RIAs based on antibodies recognizing various parts of the E-peptide has facilitated the measurement of pro-IGF-II $(12,24-26)$. Apparently, these RIAs do not to require extraction of the IGFBPs prior to analysis (24). By use of RIAs directed against the E-peptide of pro-IGF-II, a variety of biological fluids and patient categories have been assessed. Compared with normal serum, elevated levels were found in patients with NICTH, chronic renal failure and acromegaly, as well as in amniotic and seminal fluids. Serum and plasma samples from patients with growth hormone (GH) deficiency and type 1 diabetes, pregnant women and foetal chords contained levels fully comparable to those observed in normal sera. Low levels of E-peptide immunoreactivity were found in cerebral spinal fluid $(12,26)$. However, it is important to recognize that these E-peptide-specific RIAs provide no distinction between free E-peptide and intact pro-IGF-II. Therefore, van Doorn et al. (9) developed a sandwich assay similar to ours, with a coating antibody specific for the first part of the E-peptide (amino acids 68-88) and a detection antibody against mature IGF-II (amino acids 1-67). Using this assay, the authors were able to compare measurements of E-peptide by RIA and ELISA and they found a substantial discrepancy between the two methods (9). Thus, the demonstration of elevated E-peptide serum levels by the RIA needs to be accompanied by a more thorough analysis of the molecular size of the immunoreactive signal to differentiate between free E-peptide and intact pro-IGF-II. The assay developed in our laboratory detects only E-peptide when it is part of pro-IGF-II and is therefore highly specific for pro-IGF-II. Furthermore, the serum levels of pro-IGF-II comprised approximately $10 \%$ of total IGF-II in healthy subjects, but much higher levels in patients with NICTH, in line with findings by other groups $(9,12,14,26)$.

The obese subjects investigated in this study experienced a significant diet-induced weight loss followed by changes in the circulating IGF system: total and free IGF-II declined, whereas pro-IGF-II remained unaltered. As a novel finding, pro-IGF-II levels were suppressed in obese subjects when compared with age-matched controls. Total IGF-I levels increased, whereas free IGF-I remained constant. Both IGFBP-1, IGFBP-2 and IGFBP-1-bound IGF-I increased during the weight loss.

Previous studies have indicated that serum levels of free and total IGF-II are elevated in obese subjects. In this study it was not possible to directly compare IGFII concentrations in lean and obese subjects, but nevertheless the present obese cohort showed markedly higher levels of free and total IGF-II than previously observed in lean subjects with a similar age, thereby confirming earlier findings $(17,20,27)$. We now show that a diet-induced weight loss is accompanied by a reduction in free as well as total IGF-II levels, which thereby approach values in normal-weight subjects. This suggests a significant influence of nutrition on IGF-II levels. In favour of this hypothesis, significant positive correlations were observed between changes from baseline in fasting levels of serum insulin and those of total IGF-II. However, the present data do not allow us to conclude whether the correlation between IGF-II and insulin is causal or simply illustrates a biologically unrelated covariation.

To our knowledge, the nutritional regulation of pro-IGF-II levels has not previously been investigated. 
Table 2 Linear regression analysis of longitudinal data. Only significant correlations have been included.

\begin{tabular}{|c|c|c|c|c|c|}
\hline & & \multicolumn{2}{|c|}{$\begin{array}{c}\text { Change from baseline } \\
\text { to week } 8\end{array}$} & \multicolumn{2}{|c|}{$\begin{array}{c}\text { Change from baseline } \\
\text { to week } 20\end{array}$} \\
\hline & & $r$ & $P$ & $r$ & $P$ \\
\hline \multirow[t]{5}{*}{ BMI vs } & Total IGF-I & & & -0.49 & 0.004 \\
\hline & Total IGF-II & 0.39 & 0.02 & & \\
\hline & IGFBP-2 & -0.65 & $<0.001$ & -0.60 & $<0.001$ \\
\hline & IGFBP-1-bound IGF-I & 0.46 & 0.02 & & \\
\hline & Insulin & & & 0.51 & 0.02 \\
\hline \multirow[t]{4}{*}{ Pro-IGF-II vs } & Total IGF-I & 0.51 & 0.003 & 0.67 & $<0.001$ \\
\hline & Total IGF-II & 0.43 & 0.01 & & \\
\hline & Insulin & 0.37 & 0.04 & & \\
\hline & Glucose & 0.43 & 0.01 & & \\
\hline \multirow[t]{2}{*}{ Total IGF-II vs } & Insulin & 0.39 & 0.02 & 0.39 & 0.02 \\
\hline & IGFBP-2 & 0.37 & 0.03 & & \\
\hline \multirow[t]{2}{*}{ IGFBP-1 vs } & Free IGF-I & -0.39 & 0.048 & & \\
\hline & IGFBP-1-bound IGF-I & 0.56 & 0.02 & & \\
\hline \multirow[t]{3}{*}{ IGFBP-2 vs } & Free IGF-I & -0.44 & 0.03 & & \\
\hline & Total IGF-II & 0.37 & 0.03 & & \\
\hline & IGFBP-1-bound IGF-I & 0.55 & 0.003 & & \\
\hline
\end{tabular}

Our data indicate that pro-IGF-II is affected by the presence of obesity and that levels are less responsive to weight changes than the rest of the IGF system. Contrary to expectations, pro-IGF-II levels were markedly reduced in obese subjects as compared with matched controls. Thus, although pro-IGF-II did cross-react with $20 \%$ in our IGF-II assay, this is unlikely to explain the upregulation of mature IGF-II levels in obesity. It could be speculated that there is an increased enzymatic conversion of pro-IGF-II to mature peptide in obese subjects, but this remains to be clarified. On the other hand, during the study longitudinal changes in pro-IGF-II correlated positively with those of total IGF-I, and a cross-sectional analysis of data also showed positive correlations between pro-IGF-II and total IGF-I, as well as free IGF-I. Similar correlations between pro- and mature IGF-II were not found. These findings indicate that pro-IGF-II may be regulated independently of IGF-II. Supportive of this notion, Tally et al. (26) found normal pro-IGF-II levels in GH deficiency patients $(n=9)$ despite low IGF-II levels.
In lean subjects, dietary restriction is accompanied by a gradual decline in serum total IGF-I, which becomes apparent within a few days of dieting (28). In contrast, obese subjects appear to be more resistant to dietary restriction: thus, two studies have reported unchanged levels of serum total IGF-I after 3 weeks of diet (resulting in a weight loss of $5 \mathrm{~kg}$ ) (29) as well as after 13 weeks of diet (resulting in a weight loss of $15 \mathrm{~kg}$ ) (30), whereas others have observed a $40 \%$ increase in serum total IGF-I after a massive dietinduced weight loss of $30 \mathrm{~kg}$, resulting in a decline in mean BMI from 38.5 to $27.8 \mathrm{~kg} / \mathrm{m}^{2}$ (31). In the present study the diet resulted in an average weight loss of $15 \mathrm{~kg}$ (an approximate reduction in mean BMI from 38.9 to $33.8 \mathrm{~kg} / \mathrm{m}^{2}$ ) and a $27 \%$ increase in serum total IGF-I. The reason for the different responses in serum total IGF-I in lean and obese subjects remains unknown. However, insulin sensitivity increases after weight loss and this may be of importance, because insulin appears to affect IGF-I production directly as well as indirectly. Studies in cultured hepatocytes have shown that insulin stimulates IGF-I mRNA and

Table 3 Linear regression analysis of cross-sectional data.

\begin{tabular}{|c|c|c|c|c|c|c|c|}
\hline & & \multicolumn{2}{|c|}{ Baseline } & \multicolumn{2}{|c|}{ At 8 weeks } & \multicolumn{2}{|c|}{ At 29 weeks } \\
\hline & & $r$ & $P$ & $r$ & $P$ & $r$ & $P$ \\
\hline \multirow[t]{7}{*}{ Pro-IGF-II vs } & Total IGF-I & 0.57 & $<0.001$ & 0.50 & 0.003 & 0.68 & $<0.001$ \\
\hline & Free IGF-I & 0.60 & 0.001 & 0.40 & 0.02 & 0.41 & 0.02 \\
\hline & Total IGF-II & 0.27 & NS & 0.32 & NS & 0.33 & NS \\
\hline & Free IGF-II & 0.28 & NS & 0.28 & NS & 0.59 & $<0.001$ \\
\hline & IGFBP-1 & -0.45 & 0.008 & -0.19 & NS & 0.05 & NS \\
\hline & IGFBP-2 & 0.04 & NS & 0.05 & NS & 0.11 & NS \\
\hline & Insulin & 0.14 & NS & -0.19 & NS & -0.17 & NS \\
\hline Age vs & Total IGF-I & -0.43 & 0.01 & -0.63 & $<0.001$ & -0.50 & 0.003 \\
\hline
\end{tabular}

NS, non-significant. 
peptide synthesis in the absence of $\mathrm{GH}$, and that the effects of insulin are additive to those of GH (32). In addition, insulin appears to be essential for GH-stimulated hepatic IGF-I production through an upregulation of hepatic GH binding at the receptor level (33). Thus we speculate that the increase in serum total IGF-I is caused primarily by a diet-induced increase in the hepatic insulin sensitivity.

Obese subjects are characterized by a marked $\mathrm{GH}$ hyposecretion, but they are not GH-deficient since serum total IGF-I remains within the normal range $(34,35)$. This paradoxical finding has been explained by concomitant hyperinsulinaemia. Increased portal levels of insulin may at the same time upregulate the hepatic GH receptor density and hence GH sensitivity, reduce serum levels of IGFBP-1 as well as IGFBP-2 and increase free IGF-I levels $(33,36,37)$. These changes are likely to reinforce the feedback inhibition of circulating IGF-I on the pituitary GH secretion, thereby contributing to the obesity-related hyposomatropinaemia (34). Weight loss, on the other hand, is known to normalize the secretion of $\mathrm{GH}$, and in some obese cohorts it also increases serum total IGF-I (31). In the present study the diet-induced weight loss caused a significant increase in serum total IGF-I, IGFBP-1-bound IGF-I, IGFBP-1 and IGFBP-2, while free IGF-I remained constant and above the levels previously reported in lean subjects $(17,20,34)$. Normally, overnight fasting levels of free IGF-I are correlated positively with total IGF-I and inversely with IGFBP-1 and -2 (34). Thus we speculate that the positive effect of an increase in serum total IGF-I on free IGF-I is outbalanced by the increase in serum IGFBP-1 and IGFBP-2. Supportive of this hypothesis we observed an increased formation of IGFBP-1bound IGF-I after the diet.

In conclusion, we describe a highly specific as well as sensitive and precise TR-IFMA for measurement of proIGF-II in human serum. Using this assay we found that serum pro-IGF-II was markedly reduced in obese subjects, despite elevated serum levels of free and total IGF-II. Theoretically, this finding may be explained by an increased conversion of pro-IGF-II to mature peptide, but this remains to be proven. On the other hand, pro-IGF-II appeared to be less influenced by weight loss than the other components of the circulating IGF system, and cross-sectional as well as longitudinal correlation analyses indicated that pro-IGF-II was more closely associated with IGF-I than IGF-II. Thus we speculate that pro-IGF-II is regulated independently of mature IGF-II. However, further studies are needed to explore this hypothesis.

\section{Acknowledgements}

We thank Susanne Sørensen, Iben Christensen, Lenette Pedersen and Pia Hornbek for their skilled technical assistance. This study was supported by grants from the Danish Medical Research Council (to U E and J F), and the Novo Nordisk Foundation (to J F).

\section{References}

1 LeRoith D \& Roberts CT Jr. The insulin-like growth factor system and cancer. Cancer Letters 2003195 127-137.

2 Pollak MN, Schernhammer ES \& Hankinson SE. Insulin-like growth factors and neoplasia. Nature Reviews Cancer 20044 505-518.

3 De Meyts P \& Whittaker J. Structural biology of insulin and IGF1 receptors: implications for drug design. Nature Reviews Drug Discovery $20021769-783$.

4 Ghosh P, Dahms NM \& Kornfeld S. Mannose 6-phosphate receptors: new twists in the tale. Nature Reviews Molecular Cell Biology $20034202-212$.

5 Hawkes C \& Kar S. The insulin-like growth factor-II/mannose-6phosphate receptor: structure, distribution and function in the central nervous system. Brain Research Reviews $2004 \mathbf{4 4}$ 117-140.

6 LeRoith D, Werner H, Beitner-Johnson D \& Roberts CT Jr. Molecular and cellular aspects of the insulin-like growth factor I receptor. Endocrine Reviews 199516 143-163.

7 Denley A, Bonython ER, Booker GW, Cosgrove LJ, Forbes BE, Ward CW \& Wallace JC. Structural determinants for high-affinity binding of insulin-like growth factor II to insulin receptor (IR)-A, the exon 11 minus isoform of the IR. Molecular Endocrinology $2004182502-2512$.

8 Frasca F, Pandini G, Scalia P, Sciacca L, Mineo R, Costantino A, Goldfine ID, Belfiore A \& Vigneri R. Insulin receptor isoform A, a newly recognized, high-affinity insulin-like growth factor II receptor in fetal and cancer cells. Molecular Cell Biology 1999 $193278-3288$.

9 van Doorn J, Hoogerbrugge CM, Koster JG, Bloemen RJ, Hoekman K, Mudde AH \& Buul-Offers SC. Antibodies directed against the E region of pro-insulin-like growth factor-II used to evaluate non-islet cell tumor-induced hypoglycemia. Clinical Chemistry 200248 1739-1750.

10 Duguay SJ, Jin Y, Stein J, Duguay AN, Gardner P \& Steiner DF. Post-translational processing of the insulin-like growth factor-2 precursor. Analysis of O-glycosylation and endoproteolysis. Journal of Biological Chemistry 1998273 18443-18451.

11 Yang YW, Rechler MM, Nissley SP \& Coligan JE. Biosynthesis of rat insulin-like growth factor II II. Localization of mature rat insulin-like growth factor II (7484 daltons) to the amino terminus of the approximately 20-kilodalton biosynthetic precursor by radiosequence analysis. Journal of Biological Chemistry $1985 \mathbf{2 6 0}$ $2578-2582$.

12 Liu F, Baker BK, Powell DR \& Hintz RL. Characterization of proinsulin-like growth factor-II E-region immunoreactivity in serum and other biological fluids. Journal of Clinical Endocrinology and Metabolism 199376 1095-1100.

13 Hoekman K, van Doorn J, Gloudemans T, Maassen JA, Schuller AG \& Pinedo HM. Hypoglycaemia associated with the production of insulin-like growth factor II and insulin-like growth factor binding protein 6 by a haemangiopericytoma. Clinical Endocrinology $199951247-253$.

14 Zapf J, Futo E, Peter M \& Froesch ER. Can 'big' insulin-like growth factor II in serum of tumor patients account for the development of extrapancreatic tumor hypoglycemia? Journal of Clinical Investigation $1992902574-2584$.

15 Daughaday WH, Emanuele MA, Brooks MH, Barbato AL, Kapadia M \& Rotwein P. Synthesis and secretion of insulin-like growth factor II by a leiomyosarcoma with associated hypoglycemia. New England Journal of Medicine 1988319 1434-1440.

16 Zapf J. Insulin-like growth factor binding proteins and tumor hypoglycemia. Trends in Endocrinology and Metabolism 19956 $37-42$. 
17 Frystyk J, Skjærbæk C, Vestbo E, Fisker S \& Ørskov H. Circulating levels of free insulin-like growth factors in obese subjects: the impact of type 2 diabetes. Diabetes Metabolism Research and Reviews $199915314-322$.

18 Frystyk J, Dinesen B \& Ørskov H. Non-competitive time-resolved immunofluorometric assays for determination of human insulin-like growth factor I and II. Growth Regulation $1995 \mathbf{5}$ $169-176$.

19 Krassas GE, Pontikides N, Kaltsas T, Dumas A, Frystyk J, Chen JW \& Flyvbjerg A. Free and total insulin-like growth factor (IGF)-I, -II, and IGF binding protein-1, -2 , and -3 serum levels in patients with active thyroid eye disease. Journal of Clinical Endocrinology and Metabolism $2003 \mathbf{8 8} 132-135$.

20 Frystyk J, Skjærbæk C, Dinesen B \& Ørskov H. Free insulin-like growth factors (IGF-I and IGF-II) in human serum. FEBS Letters $1994348185-191$.

21 Frystyk J, Højlund K, Rasmussen KN, Jørgensen SP, WildnerChristensen M \& Ørskov H. Development and clinical evaluation of a novel immunoassay for the binary complex of IGF-I and IGF-binding protein-1 in human serum. Journal of Clinical Endocrinology and Metabolism 200287 260-266.

22 Bruun JM, Pedersen SB, Kristensen K \& Richelsen B. Opposite regulation of interleukin- 8 and tumor necrosis factor-alpha by weight loss. Obesity Research 200210 499-506.

23 Daughaday WH \& Kapadia M. Significance of abnormal serum binding of insulin-like growth factor II in the development of hypoglycemia in patients with non-islet-cell tumors. PNAS 1989 $866778-6782$.

24 Perdue JF, LeBon TR, Kato J, Hampton B \& Fujita-Yamaguchi Y. Binding specificities and transducing function of the different molecular weight forms of insulin-like growth factorII (IGF-II) on IGF-I receptors. Endocrinology 1991129 3101-3108.

25 Daughaday WH \& Trivedi B. Measurement of derivatives of proinsulin-like growth factor-II in serum by a radioimmunoassay directed against the E-domain in normal subjects and patients with nonislet cell tumor hypoglycemia. Journal of Clinical Endocrinology and Metabolism 199275 110-115.

26 Tally M, Eriksson U, Thoren M, Brismar K \& Hall K. Immunoreactive proinsulin-like growth factor-II levels in healthy subjects, patients with growth hormone deficiency, and patients with type 1 diabetes: effects of insulin-like growth factor-I and insulin. Journal of Clinical Endocrinology and Metabolism 1994 $791576-1581$.
27 Frystyk J, Vestbo E, Skjærbæk C, Mogensen CE \& Ørskov H. Free insulin-like growth factors in human obesity. Metabolism 1995 $4437-44$.

28 Thissen JP, Ketelslegers JM \& Underwood LE. Nutritional regulation of the insulin-like growth factors. Endocrine Reviews 1994 $1580-101$.

29 Gama R, Teale JD \& Marks V. The effect of synthetic very low calorie diets on the GH-IGF-1 axis in obese subjects. Clinica Chimica Acta $1990 \mathbf{1 8 8} 31-38$.

30 Snyder DK, Clemmons DR \& Underwood LE. Treatment of obese, diet-restricted subjects with growth hormone for 11 weeks: effects on anabolism, lipolysis, and body composition. Journal of Clinical Endocrinology and Metabolism 198867 54-61.

31 Rasmussen MH, Hvidberg A, Juul A, Main KM, Gotfredsen A, Hilsted J \& Skakkebæk NE. Massive weight loss restores 24-hour growth hormone release profiles and serum insulin-like growth factor-I levels in obese subjects. Journal of Clinical Endocrinology and Metabolism $1995 \mathbf{8 0} 1407-1415$.

32 Böni-Schnetzler M, Schmid C, Meier PJ \& Froesch ER. Insulin regulates insulin-like growth factor I mRNA in rat hepatocytes. American Journal of Physiology, Endocrinology and Metabolism 1991260 E846-E851.

33 Leung KC, Doyle N, Ballesteros M, Waters MJ \& Ho KK. Insulin regulation of human hepatic growth hormone receptors: divergent effects on biosynthesis and surface translocation. Journal of Clinical Endocrinology and Metabolism $2000 \mathbf{8 5} 4712-4720$.

34 Frystyk J. Free insulin-like growth factors - measurements and relationships to growth hormone secretion and glucose homeostasis. Growth Hormone and IGF Research $200414337-375$.

35 Scacchi M, Pincelli AI \& Cavagnini F. Growth hormone in obesity. International Journal of Obesity and Related Metabolic Disorders $199923260-271$.

36 Conover CA, Lee PD, Kanaley JA, Clarkson JT \& Jensen MD. Insulin regulation of insulin-like growth factor binding protein-1 in obese and nonobese humans. Journal of Clinical Endocrinology and Metabolism $1992 \mathbf{7 4} 1355-1360$.

37 Ooi GT, Tseng LY \& Rechler MM. Post-transcriptional regulation of insulin-like growth factor binding protein-2 mRNA in diabetic rat liver. Biochemical and Biophysical Research Communications $19921891031-1037$.

Received 18 May 2005

Accepted 1 September 2005 